\title{
INFLUENCE OF PHENOLIC COMPOUNDS ON THE GROWTH AND ARGININE DEIMINASE SYSTEM IN A WINE LACTIC ACID BACTERIUM
}

\author{
María R. Alberto ${ }^{1}$, María C. Manca de Nadra ${ }^{1,2 ;+}$, Mario E. Arena ${ }^{1,2^{*}}$ \\ ${ }^{1}$ Centro Científico Tecnológico CCT-CONICET. Tucumán, Argentina; ${ }^{2}$ Facultad de Bioquímica, Química y Farmacia. UNT. \\ Tucumán, Argentina.
}

Submitted: November 07, 2010; Returned to authors for corrections: July 01, 2011; Approved: August 30, 2011.

\begin{abstract}
The influence of seven phenolic compounds, normally present in wine, on the growth and arginine deiminase system (ADI) of Lactobacillus hilgardii $\mathrm{X}_{1} \mathrm{~B}$, a wine lactic acid bacterium, was established. This system provides energy for bacterial growth and produces citrulline that reacts with ethanol forming the carcinogen ethyl carbamate (EC), found in some wines. The influence of phenolic compounds on bacterial growth was compound dependent. Growth and final $\mathrm{pH}$ values increased in presence of arginine. Arginine consumption decreased in presence of protocatechuic and gallic acids (31 and 17\%, respectively) and increased in presence of quercetin, rutin, catechin and the caffeic and vanillic phenolic acids (between 10 and $13 \%$, respectively). ADI enzyme activities varied in presence of phenolic compounds. Rutin, quercetin and caffeic and vanillic acids stimulated the enzyme arginine deiminase about 37-40\%. Amounts of 200 $\mathrm{mg} / \mathrm{L}$ gallic and protocatechuic acids inhibited the arginine deiminase enzyme between 53 and 100\%, respectively. Ornithine transcarbamylase activity was not modified at all concentrations of phenolic compounds. As gallic and protocatechuic acids inhibited the arginine deiminase enzyme that produces citrulline, precursor of EC, these results are important considering the formation of toxic compounds.
\end{abstract}

Key words: polyphenols, arginine, Lactobacillus hilgardii

\section{INTRODUCTION}

Lactic acid bacteria (LAB) can interact with wine, altering its composition in ways that, under certain circumstances, may be considered beneficial or detrimental to the quality of the final product (14). The positive interactions involve malolactic fermentation while the negative ones include the formation of biogenic amines (7) and carcinogenic precursors (8, 10). Lactobacillus hilgardii is a very common heterofermentative bacterium found in wine, associated mainly with several kinds of negative alterations (42). Arginine is quantitatively one of the most important amino acids found in wine. Some wine LAB are known to degrade L-arginine, with the formation of ornithine and ammonia $(8,23,24,27,41)$. It has been demonstrated that arginine catabolism by wine LAB involves the arginine deiminase (ADI) pathway. In a previous paper, Arena et al. (10) demonstrated that L. hilgardii $\mathrm{X}_{1} \mathrm{~B}$ degraded arginine to citrulline, ornithine and ammonia; and that

\footnotetext{
*Corresponding Author. Mailing address: Ayacucho 491 (4000) Tucumán, Argentina.; Fax: 54-381-4248169.; E-mail: arename@ fbqf.unt.edu.ar ${ }^{+}$Author died in 2009
} 
citrulline and ornithine were consumed. In this strain the $\operatorname{arc} \mathrm{A}$, $\operatorname{arc} \mathrm{B}$, and $\operatorname{arc} \mathrm{C}$ genes form an operon and encode the enzymes arginine deiminase, ornithine transcarbamoylase, and carbamate kinase, respectively (9). In addition, gene and enzyme activities of the ADI system were reported in other wine $\operatorname{LAB}(11,36,37)$.

Arginine catabolism via ADI could be an important energy source for bacterial growth and involves three enzymatic reactions:

Arginine deiminase
L-arginine $+\mathrm{H}_{2} \mathrm{O} \rightarrow \quad$ L-citrulline $+\mathrm{NH}_{3}$
Ornithine transcarbamylase
L-citrulline $+\mathrm{P}_{\mathrm{i}} \quad \leftrightarrow \quad$ L-ornithine + carbamyl-P

Carbamate kinase

Carbamyl-P + ADP $\leftrightarrow \quad \mathrm{ATP}+\mathrm{CO}_{2}+\mathrm{NH}_{3}$

Another concern about arginine metabolism by wine LAB is the formation of ethyl carbamate (EC) precursors. EC, also referred to as urethane, is a known animal carcinogen (28) found in fermented foods and beverages including wine (39). EC formation is a spontaneous chemical reaction involving ethanol and a compound that contains a carbamyl group such as urea, citrulline and carbamyl phosphate. The US Food and Drug Administration (43) has published recommendations to minimize EC in wine.

Fermented beverages are complex systems with a wide number of factors influencing the metabolic activities of microorganisms. A large host of factors has been observed to affect the wine bacterial metabolism including temperature, $\mathrm{pH}$, amino acids, organic acids, ethanol and sugar concentrations $(24,30)$.

Phenolic compounds, one of the most abundant groups of chemical compounds in grapes, are responsible for color, taste, mouth feel, oxidation, and other chemical reactions in wine and juice. They have received considerable attention because of their potential antioxidant activity (20, 22); hence, the production of phenolic compounds has become a novel industry $(12,18)$. The presence of polyphenols in wines vary according to many factors, like grape variety, cultural practices, local climate conditions, vinification techniques, storage and aging. Red wine is a source of various classes of polyphenols, mainly phenol carboxylic acids (100-200 mg/L), catechin $(10-400 \mathrm{mg} / \mathrm{L})$, quercetin $(5-20 \mathrm{mg} / \mathrm{L})(17,25)$. The effect of phenolic compounds on LAB growth and metabolism has been studied $(2,3,4,14,15,31,34,44)$ as well as the phenolic degradation by $\operatorname{LAB}(5,16)$

To gain a deeper insight into the arginine catabolism of $L$. hilgardii $\mathrm{X}_{1} \mathrm{~B}$ we studied the phenolic compounds interaction on arginine utilization and enzymatic reactions involved in the ADI pathway. The aim of this work is to study the effects of pure wine phenolic compounds like flavonoids and phenolic acids on the growth and arginine metabolism of $L$. hilgardii $\mathrm{X}_{1} \mathrm{~B}$, a strain able to produce EC precursors.

\section{MATERIALS AND METHODS}

\section{Organism}

Lactobacillus hilgardii $\mathrm{X}_{1} \mathrm{~B}$ was isolated from Argentinean wine (40).

\section{Chemicals}

Gallic acid was obtained from Merck, catechin was supplied by Sigma (USA) while vanillic acid, quercetin, protocatechuic acid, rutin and caffeic acid were purchased from ICN (USA).

\section{Culture Media}

The basal medium (BM) contained, in $\mathrm{g} / \mathrm{L}$, peptone (Britania, Argentina), 5; yeast extract (Britania, Argentina), 3; glucose (Cicarelli, Argentina), 1; L-arginine (Sigma, USA), 1 and $10 \%$ tomato juice. The media were adjusted to $\mathrm{pH} 4.5$ with $1 \mathrm{mM} \mathrm{KOH}$ before autoclaving at $121{ }^{\circ} \mathrm{C}$ for $20 \mathrm{~min}$. Phenolic compound solutions were prepared in ethanol. All 
media were adjusted to a final ethanol content of $7 \%(\mathrm{v} / \mathrm{v})$. The filter-sterilized phenolic compounds were added to the autoclaved media to reach the final concentration normally present in red wine $(100 \mathrm{mg} / \mathrm{L}$ for gallic, vanillic and protocatechuic acids, $10 \mathrm{mg} / \mathrm{L}$ for caffeic acid, $50 \mathrm{mg} / \mathrm{L}$ for rutin and quercetin and $200 \mathrm{mg} / \mathrm{L}$ for catechin).

\section{Growth conditions and culture procedure}

L. hilgardii $\mathrm{X}_{1} \mathrm{~B}$ was grown in $\mathrm{BM}$. After incubation at 30 ${ }^{\circ} \mathrm{C}$ for $24 \mathrm{~h}$, the cells from the third subculture were harvested by centrifugation $\left(5000 \mathrm{~g}\right.$ for $20 \mathrm{~min}$ at $4^{\circ} \mathrm{C}$ ), washed with sterile distilled water, and resuspended in sterile distilled water to $\mathrm{OD}_{560 \mathrm{~nm}}=0.90$. This bacterial suspension was used to inoculate the experimental media at a rate of $12 \%(\mathrm{v} / \mathrm{v})$. These cultures were incubated in darkness at $30^{\circ} \mathrm{C}$ for $50 \mathrm{~h}$ without shaking and the samples were taken and stored frozen $\left(-20^{\circ} \mathrm{C}\right)$ for subsequent chemical analyses. Each experiment was carried out in triplicate.

\section{Bacterial growth evaluation}

Bacterial growth was monitored by periodic measurement of optical density at $560 \mathrm{~nm}$ using a microplate reader (Molecular Devices, VERSAmax).

\section{Analytical methods}

Arginine, citrulline and ornithine concentration were determined by HPLC analysis, using the method described by Alberto et al. (1). Ammonia was determined by indophenol blue reaction (35). Glucose was analyzed by the glucose oxidase method (Kits from Wiener, Lab. Rosario, Argentina). Protein was quantified by Bradford's method (13) Phenolic compounds were determined by HPLC (5).

\section{Enzymes assay}

L. hilgardii $\mathrm{X}_{1} \mathrm{~B}$ was grown in $\mathrm{BM}$ at $30^{\circ} \mathrm{C}$. Cultures were harvested at the end of the logarithmic phase growth by centrifugation at $12,000 \mathrm{rpm}$ for $15 \mathrm{~min}$ and the pellet was washed twice with the appropriate buffer. To determine arginine deiminase activity, twenty-five $\mathrm{mg}$ per milliliter of bacterial pellets were resuspended in $0.2 \mathrm{M}$ sodium phosphate buffer at $\mathrm{pH}$ 6.5. To determine ornithine transcarbamylase activity, they were resuspended in $0.2 \mathrm{M}$ sodium acetate buffer, $\mathrm{pH}$ 5.8. To prepare cell extracts, cell pellets were passed four times through a French press. Cell debris was removed by centrifugation at $15,000 \mathrm{rpm}$ for $5 \mathrm{~min}$, and the supernatant extract was used to determine enzyme activities (37).

For both enzymes the specific buffer was added different phenolic compounds in the range of concentrations normally present in wines: gallic, protocatechuic and vanillic phenolic acids 50-200 mg/L; caffeic acid 10-20 mg/L and the flavonoids quercetin and rutin $25-50 \mathrm{mg} / \mathrm{L}$ and catechin 50-200 mg/L. The reaction mixture without a phenolic compound was used as control.

Specific activity was defined as the micrograms of substrate consumed per minute per $\mu \mathrm{g}$ of protein.

Enzyme activities were determined according to the method proposed by Oginsky (29). The reaction mixture for arginine deiminase determination had the following composition in a final volume of $3.6 \mathrm{~mL}$ : $0.4 \mathrm{~mL}$ L-arginine$\mathrm{HCl}(0.1 \mathrm{M})$ adjusted to $\mathrm{pH} 6.5 ; 1 \mathrm{~mL}$ sodium phosphate buffer (0.2 M), pH 6.5; $0.6 \mathrm{~mL}$ cell extracts, and $1.6 \mathrm{~mL}$ distilled water. The mixture was incubated at $30{ }^{\circ} \mathrm{C}$, and samples were taken every $15 \mathrm{~min}$. The reaction was stopped by the addition of $0.2 \mathrm{~mL}$ perchloric acid (70\%). The samples were centrifuged at $4000 \mathrm{~g}$ for $30 \mathrm{~min}$ at $4{ }^{\circ} \mathrm{C}$, and citrulline was determined in the supernatant.

The reaction mixture for ornithine transcarbamylase determination had the following composition in a final volume of $3.6 \mathrm{~mL}: 1 \mathrm{~mL}$ L-citrulline- $\mathrm{HCl}(0.1 \mathrm{M}) ; 1 \mathrm{~mL}$ sodium acetate buffer $(0.5 \mathrm{M}), \mathrm{pH} 5.8 ; 1 \mathrm{~mL}$ sodium arsenate $(0.1 \mathrm{M})$, and $0.6 \mathrm{~mL}$ cell extracts. The mixture was incubated at $30^{\circ} \mathrm{C}$, and samples were taken every $15 \mathrm{~min}$. The reaction was stopped by the addition of $0.2 \mathrm{~mL}$ perchloric acid (70\%). The samples were centrifuged at $4000 \mathrm{~g}$ for $30 \mathrm{~min}$ at $4{ }^{\circ} \mathrm{C}$, and ornithine was determined in the supernatant. 


\section{Statistical analysis}

MINITAB Student test was used. Three replicate determinations were carried out.

\section{RESULTS AND DISCUSSION}

Effect of arginine and phenolic compounds on $L$. hilgardii $\mathrm{X}_{1} \mathrm{~B}$ growth

The comparative analysis of the influence of arginine on $L$. hilgardii $\mathrm{X}_{1} \mathrm{~B}$ growth in the media added with different phenolic compounds shows that the addition of arginine to BM increased $L$. hilgardii $\mathrm{X}_{1} \mathrm{~B}$ growth $75,55,71$ and $28 \%$ in presence of gallic, vanillic, protocatechuic, and caffeic phenolic acids and 57, 63 and $67 \%$ in presence of the flavonoids rutin, quercetin and catechin, with respect to the same media without arginine (Table 1). These results indicated that independently of the phenolic compounds added to the media, arginine is able to enhance bacterial development.

Table 1. Effect of phenolic compounds and arginine on L. hilgardii $\mathrm{X}_{1} \mathrm{~B}$ growth

\begin{tabular}{lccc}
\hline \multicolumn{1}{c}{ Samples } & $\begin{array}{c}\text { Phenolic } \\
\text { concentration } \\
(\mathbf{m g} / \mathbf{L})\end{array}$ & $\mathbf{B M}$ & OD 560 \\
\cline { 3 - 4 } & - & $0.390 \pm 0.011$ & BM + Arginine \\
\hline Control & 100 & $0.365 \pm 0.014$ & $0.6409 \pm 0.020$ \\
Gallic acid & 100 & $0.432 \pm 0.013$ & $0.670 \pm 0.021$ \\
Vanillic acid & 100 & $0.381 \pm 0.011$ & $0.619 \pm 0.019$ \\
Protocatechuic acid & 10 & $0.534 \pm 0.014$ & $0.685 \pm 0.020$ \\
Caffeic acid & 50 & $0.538 \pm 0.014$ & $0.842 \pm 0.025$ \\
Rutin & 50 & $0.416 \pm 0.015$ & $0.676 \pm 0.020$ \\
Quercetin & 200 & $0.541 \pm 0.015$ & $0.903 \pm 0.027$ \\
Catechin & & &
\end{tabular}

On the other hand, the influence of phenolic compounds on the growth of L. hilgardii $\mathrm{X}_{1} \mathrm{~B}$ was evaluated with and without arginine (Table 1).

In the media without arginine caffeic acid, rutin and catechin showed a similar stimulatory effect of nearly $38 \%$, and vanillic acid showed a stimulatory effect of about $11 \%$. Gallic acid, protocatechuic acid and quercetin did not modify bacterial growth, with respect to the control media without arginine and phenolic compounds.

In the presence of arginine, the flavonoids rutin and catechin, stimulated bacterial growth 19 and 27\%, respectively. Protocatechuic and gallic acids showed an inhibitory effect of 13 and $10 \%$, respectively. The other phenolic compounds did not affect the growth of $L$. hilgardii, compared with the control media with arginine but without phenolic compounds.

The different results observed in presence or absence of arginine, suggest that there is an interaction between arginine metabolism by L. hilgardii $\mathrm{X}_{1} \mathrm{~B}$ and some of the phenolic compounds. According to the results for L. hilgardii, Reguant et al. (31) demonstrated in Oenococcus oeni isolated from wine that catechin showed a stimulating effect and quercetin caused a slight increase in growth. Alberto et al. (3), reported in a wine lactic acid bacterium, L. hilgardii $5 \mathrm{w}$, that gallic acid and $(+)$-catechin at concentrations normally present in wine, not only stimulated the growth rate but also resulted in greater cell densities during the stationary growth phase. They also reported (4) that there is an inverse relation between total phenolic concentration in wine media and cell viability and a direct relation between L. hilgardii $5 \mathrm{w}$ tannin binding and its viability loss. Figueiredo et al. (21) investigated the effect of phenolic aldehydes and flavonoids on the growth and inactivation of $O$. oeni $\mathrm{VF}$ and L. hilgardii 5. Among the phenolic aldehydes tested, L. hilgardii was only inhibited by sinapaldehyde and coniferaldehyde while $O$. oeni growth was 
significantly inhibited by five of them. Among the flavonoids, quercetin and kaempferol exerted an inhibitory effect especially on $O$. oeni. Myricetin and the flavan-3-ols studied (catechin and epicatechin) did not affect the growth of both strains considerably. In general, $O$. oen $i$ was found to be more sensitive to the phenolic compounds studied than L. hilgardii 5.

Arginine consumed and citrulline, ornithine and ammonia

\section{produced by $L$. hilgardii $\mathrm{X}_{1} \mathrm{~B}$}

Table 2 shows the influence of polyphenols added to the media on arginine metabolism, after $50 \mathrm{~h}$ incubation at $30^{\circ} \mathrm{C}$. Only in presence of protocatechuic and gallic acids arginine consumption was 31 and $17 \%$ lower than that observed in the control media. The presence of vanillic and caffeic acids, rutin, quercetin or catechin increased arginine consumption between 10 and $13 \%$.

Table 2. Influence of phenolic compounds on arginine metabolism by L. hilgardii $\mathrm{X}_{1} \mathrm{~B}$ after $50 \mathrm{~h}$ incubation at $30^{\circ} \mathrm{C}$.

\begin{tabular}{lcccc}
\hline \multicolumn{1}{c}{ Samples } & Consumed & \multicolumn{3}{c}{ Produced } \\
\cline { 2 - 5 } & $\begin{array}{c}\text { Arginine } \\
(\mathbf{m m o l} / \mathbf{L})\end{array}$ & $\begin{array}{c}\text { Citrulline } \\
\text { (mmol/L) }\end{array}$ & $\begin{array}{c}\text { Ornithine } \\
\text { (mmol/L) }\end{array}$ & $\begin{array}{c}\text { Ammonia } \\
(\mathbf{m m o l} / \mathbf{L})\end{array}$ \\
\hline Control & $4.28 \pm 0.12$ & $0.79 \pm 0.04$ & $2.99 \pm 0.09$ & $6.55 \pm 0.25$ \\
Gallic acid & $3.57 \pm 0.09$ & $0.70 \pm 0.04$ & $2.94 \pm 0.12$ & $5.90 \pm 0.21$ \\
Vanillic acid & $4.69 \pm 0.12$ & $0.76 \pm 0.06$ & $3.19 \pm 0.17$ & $6.42 \pm 0.19$ \\
Protocatechuic acid & $2.94 \pm 0.10$ & $0.67 \pm 0.05$ & $2.37 \pm 0.11$ & $5.28 \pm 0.21$ \\
Caffeic acid & $4.73 \pm 0.08$ & $0.64 \pm 0.06$ & $3.24 \pm 0.10$ & $6.96 \pm 0.18$ \\
Rutin & $4.75 \pm 0.10$ & $0.68 \pm 0.04$ & $3.69 \pm 0.12$ & $7.43 \pm 0.21$ \\
Quercetin & $4.82 \pm 0.09$ & $0.74 \pm 0.09$ & $3.45 \pm 0.09$ & $7.32 \pm 0.20$ \\
Catechin & $4.72 \pm 0.12$ & $0.91 \pm 0.05$ & $3.13 \pm 0.09$ & $6.40 \pm 0.29$ \\
\hline
\end{tabular}

The citrulline remaining in the medium is the result of the balance between arginine degradation and citrulline consumption. In presence of gallic, protocatechuic and caffeic acids and rutin the citrulline present in the media was 11,15 , 19 and $14 \%$ lower than in the control without phenolic compound. Citrulline increased $15 \%$ in presence of catechin and its concentration was not modified by the other polyphenolic compounds. The reason for citrulline excretion remains obscure, as there is no obvious energetic advantage to be gained in this process. However, its association with ammonium excretion increases the external $\mathrm{pH}$, which is positive for cells in an acid environment (45).

The ornithine formed from arginine via citrulline diminished $21 \%$ by the presence of protocatechuic acid and increased 23 and $15 \%$ in presence of rutin and quercetin, respectively. Arginine recovery consumed as citrulline plus ornithine was in all cases higher than $82 \%$.
A decrease in ammonia formation was observed in presence of protocatechuic (19\%) and gallic (9\%) acids, but an increase of 12 and $13 \%$ was observed in presence of quercetin and rutin, respectively. The influence of ammonia formed in the final $\mathrm{pH}$ values was observed.

In all the media the final $\mathrm{pH}$ values were nearly 3 units higher in presence of arginine (between 6.9 and 7.3) than in $\mathrm{BM}$ without this amino acid (between 4.0 and 4.2). No significant differences were observed between the media with arginine and the different phenolic compounds. The different $\mathrm{pH}$ values observed in presence or absence of arginine could have an influence in phenolic compounds transport or utilization.

Arena and Manca de Nadra (8) reported that L. hilgardii $\mathrm{X}_{1} \mathrm{~B}$, after 30 days of incubation at $30^{\circ} \mathrm{C}$ in the same growing conditions used in the present work, is able to metabolize arginine in order to produce EC. Arginine metabolism 
by $L$. hilgardii $\mathrm{X}_{1} \mathrm{~B}$ increases the amount of citrulline, allowing EC production in the medium. The bacterial metabolism increased EC formation threefold in absence of ethanol and eightfold in presence of ethanol with respect to the same media without bacteria inoculation. Our results suggested that citrulline excreted to the medium during arginine catabolism may lead to important amounts of EC that would overcome the maximum levels of EC allowed in USA wines $(15 \mathrm{ng} / \mathrm{mL})$, even though the conversion of citrulline into EC is not stoichiometric. Moreover, less than $1 \%$ of citrulline was converted into EC at room temperature (8).

\section{Glucose utilization in the different media}

As the ADI pathway produces energy as ATP, Fig. 1 shows the effect of phenolic compounds on glucose consumption by $L$. hilgardii $\mathrm{X}_{1} \mathrm{~B}$ in presence or absence of arginine.
It is well known that arginine may serve as an energy source for $L$. hilgardii $\mathrm{X}_{1} \mathrm{~B}$ strain (10). The higher residual glucose in the media with arginine than in the ones without it, suggests clearly that the energy provided by arginine is able to diminish glucose requirements in nearly all the media assayed.

On the other hand, in absence of arginine, only the addition of gallic acid increased glucose consumption. In contrast, glucose consumption was lower in presence of arginine only with vanillic acid. Glucose consumption was higher with the other phenolics.

A relation between glucose consumption and growth observed in the different media added with polyphenolics was not observed. Hence, it may be suggested that growth modification is a consequence of the phenolic compounds themselves rather than sugar degradation, especially so when we consider that in all cases at least $92 \%$ glucose was consumed.

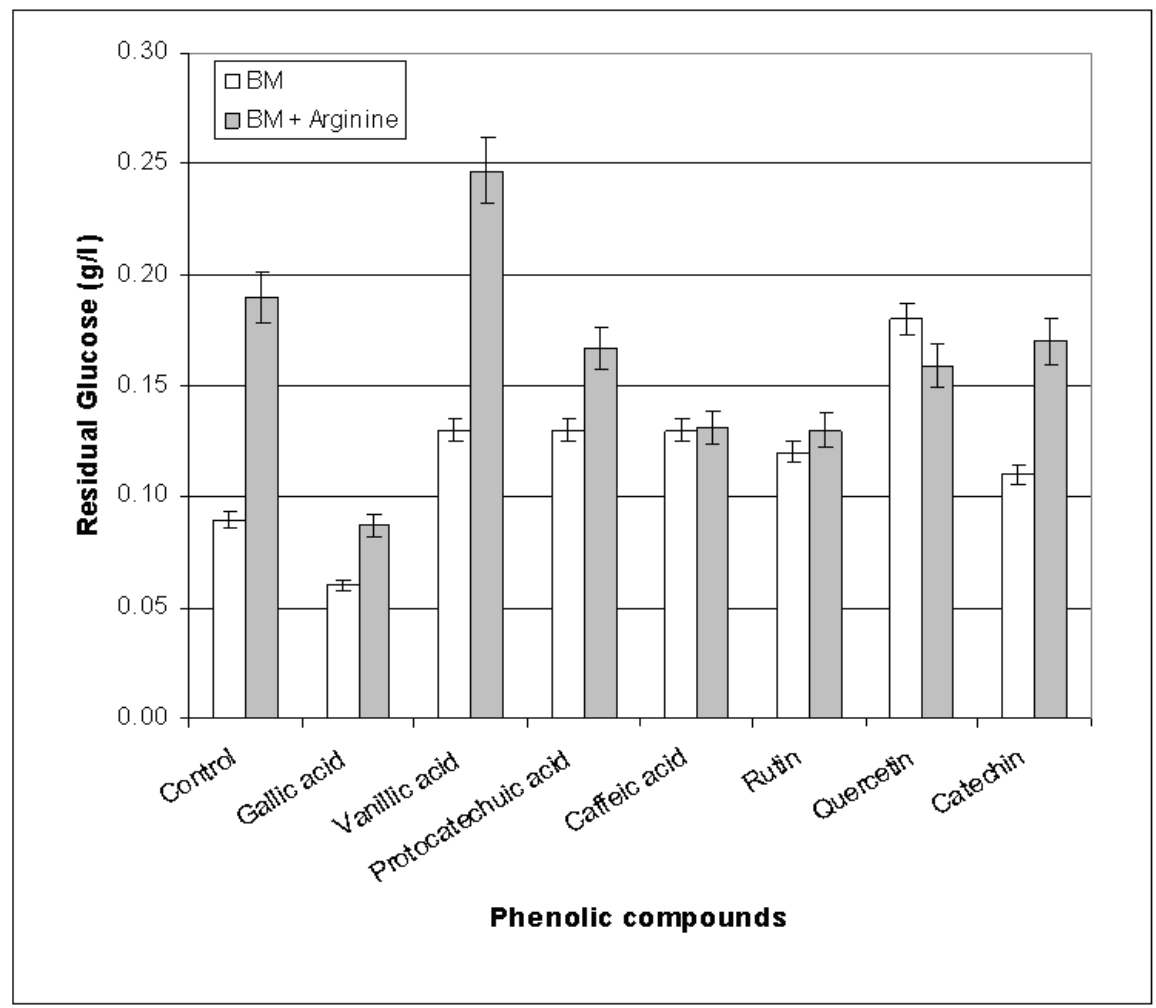

Figure 1. Residual glucose after $50 \mathrm{~h}$ incubation in the different media inoculated with L. hilgardii. Each value is the mean of three replicates $\pm \mathrm{SD}(p \leq 0.05)$. 
Modification of phenolic compounds concentration by $L$. hilgardii $\mathrm{X}_{1} \mathrm{~B}$

Fig. 2 shows the decrease in phenolic compounds concentration after $50 \mathrm{~h}$ incubation with or without arginine. In the media without arginine, rutin, catechin, protocatechuic, vanillic and caffeic acids disappeared partially, 10, 28, 12, 8, and $82 \%$, respectively. In the media with arginine, gallic and protocatechuic acids and quercetin decreased 61, 10 and 81\%, respectively. The higher consumption of vanillic and caffeic acids, rutin and catechin in BM than in BM plus arginine could partially explain the stimulatory effect observed in bacterial growth due to their addition with respect to BM without phenolic compounds.
Some Lactobacillus species metabolize hydroxycinnamic acids at low concentrations by reduction to ethyl phenols (38) and vinyl derivatives (19). In addition, Alberto et al. (5) demonstrated the degradation of gallic acid and catechin by $L$. hilgardii 5w. In gallic acid-grown cultures, gallic acid, pyrogallol, catechol, protocatechuic acid, p-hydroxybenzoic acid, $p$-hydroxybenzaldehyde and $p$-hydroxybenzylalcohol were detected. In catechin-grown cultures, catechin, gallic acid, pyrogallol, catechol, $p$-hydroxybenzoic acid, acetovanillone, and homovanillic acid were detected. Moreover, Lactobacillus plantarum and Lactobacillus brevis strains were able to decarboxilate gallic and protocatechuic acid to pyrogallol and catechol, respectively $(19,30)$.

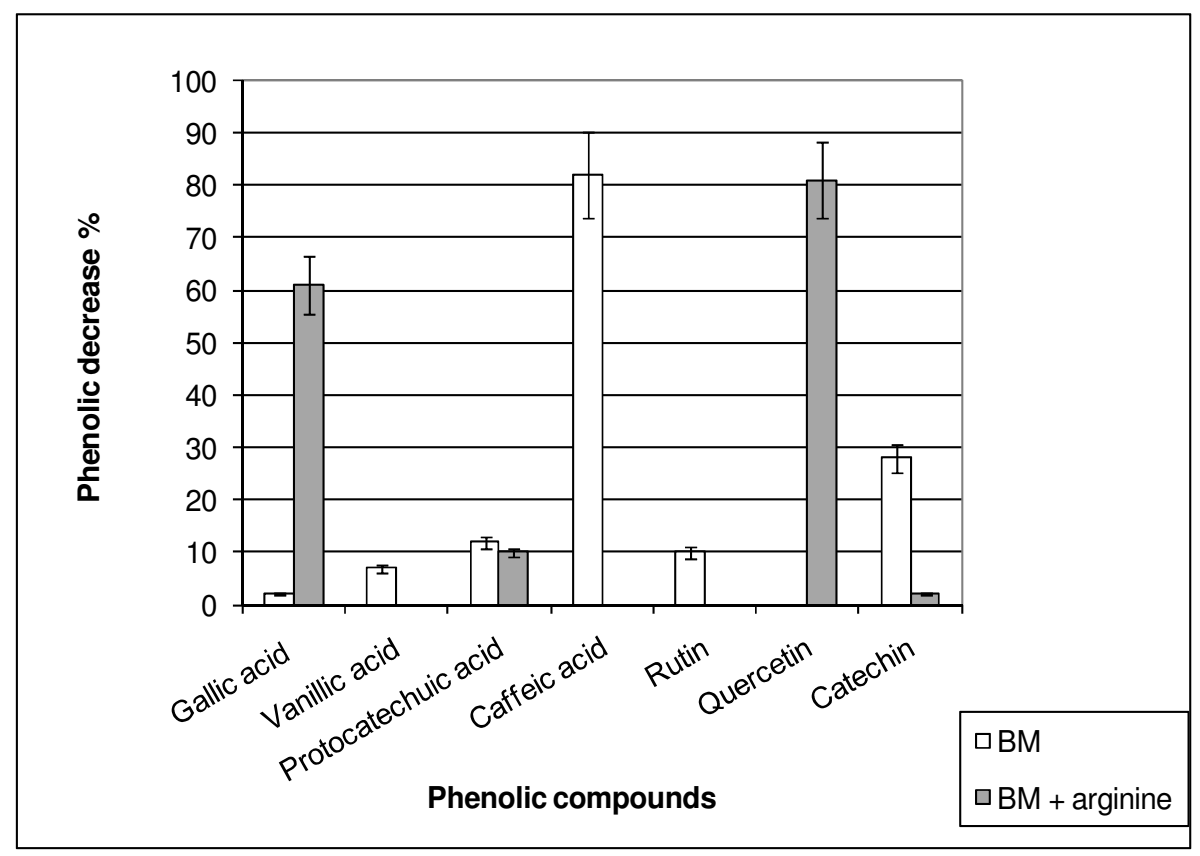

Figure 2. Decrease (\%) in the phenolic compound concentrations after $50 \mathrm{~h}$ incubation of Lactobacillus hilgardii in BM and BM + arginine. Initial concentration for gallic, vanillic and protocatechuic acids $100 \mathrm{mg} / \mathrm{L}$; caffeic acid $10 \mathrm{mg} / \mathrm{L}$; rutin and quercetin $50 \mathrm{mg} / \mathrm{L}$ and catechin $200 \mathrm{mg} / \mathrm{L}$.

\section{Arginine deiminase and ornithine transcarbamylase activities}

In previous papers, Arena et al. $(8,10)$ demonstrated that L. hilgardii $\mathrm{X}_{1} \mathrm{~B}$ degraded arginine to citrulline, ornithine and ammonia, and that citrulline and ornithine were consumed. In addition, Tonon and Lonvaud-Funel (42) reported that all $L$. hilgardii strains studied have the ability to degrade arginine via the ADI system. 
In this paper we studied the influence of phenolic compounds on the activities of the enzymes involved in arginine and citrulline degradation. Table 3 shows the activities of arginine deiminase and catabolic ornithine transcarbamylase in cells of $L$. hilgardii $\mathrm{X}_{1} \mathrm{~B}$ after $50 \mathrm{~h}$ incubation in presence of arginine and different phenolic compounds.

Table 3. Specific activities of arginine deiminase and ornithine transcarbamylase enzymes by resting cells of $L$. hilgardii $\mathrm{X}_{1} \mathrm{~B}$.

\begin{tabular}{lccc}
\hline Sample & $\begin{array}{c}\text { Phenolic } \\
\text { concentration } \\
(\mathbf{m g} / \mathbf{L})\end{array}$ & $\begin{array}{c}\text { Arginine } \\
\text { deiminase } \\
(\mathbf{m g} / \mathbf{m i n} / \mathbf{\mu g}) \mathbf{~} \mathbf{1 . 1 0}\end{array}$ & $\begin{array}{c}\text { Ornithine } \\
\text { transcarbamylase } \\
(\mathbf{m g} / \mathbf{m i n} / \mathbf{\mu g}) \mathbf{~} \mathbf{1 . 1 0}\end{array}$ \\
\hline Control & 0 & $30 \pm 1$ & $35 \pm 1$ \\
Gallic acid & 50 & $24 \pm 2$ & $37 \pm 2$ \\
& 100 & $20 \pm 1$ & $37 \pm 1$ \\
Vanillic acid & 200 & $14 \pm 2$ & $37 \pm 3$ \\
& 50 & $42 \pm 2$ & $40 \pm 2$ \\
Protocatechuic acid & 100 & $42 \pm 1$ & $41 \pm 2$ \\
& 200 & $42 \pm 1$ & $41 \pm 2$ \\
Caffeic acid & 50 & $19 \pm 1$ & $37 \pm 2$ \\
Rutin & 100 & $12 \pm 3$ & $36 \pm 2$ \\
& 200 & $0 \pm 1$ & $35 \pm 3$ \\
Quercetin & 10 & $41 \pm 1$ & $40 \pm 2$ \\
Catechin & 20 & $42 \pm 2$ & $39 \pm 1$ \\
& 25 & $38 \pm 1$ & $39 \pm 2$ \\
& 50 & $41 \pm 1$ & $40 \pm 1$ \\
& 25 & $41 \pm 2$ & $40 \pm 1$ \\
& 50 & $41 \pm 3$ & $39 \pm 1$ \\
& 50 & $27 \pm 2$ & $37 \pm 3$ \\
& 100 & $36 \pm 1$ & $38 \pm 2$ \\
& 200 & $39 \pm 2$ & $38 \pm 3$ \\
\hline
\end{tabular}

Independently of phenolic concentration, in presence of caffeic and vanillic acids and quercetin, arginine deiminase activity was about $37-40 \%$ higher than in the control without phenolic compounds. In presence of rutin and catechin, enzyme activity was higher when phenolic concentrations increased. The values were 27 and $37 \%$ higher in presence of 25 and 50 $\mathrm{mg} / \mathrm{L}$ rutin, respectively; and 20 and $30 \%$ higher in presence of 100 and $200 \mathrm{mg} / \mathrm{L}$ catechin, respectively. Different results were observed in presence of gallic and protocatechuic acids. These phenolic acids at 50, 100 and $200 \mathrm{mg} / \mathrm{L}$ decreased the activity of the first enzyme of the ADI system by 20,33 and $53 \%$ for gallic acid and 37, 60 and 100\% for protocatechuic acid, respectively. These results are related to the effect of gallic and protocatechuic acids on arginine consumption (Table 2).

Ornithine transcarbamylase activity was not modified at all concentrations of phenolic compounds and only little increments of about $10 \%$ were observed (Table 3 ).

The results shown in this work indicate that phenolic acids can influence growth parameters. Some authors have reported that wine $\mathrm{LAB}$ growth could be modified by phenolic compounds $(3,4,31)$. The differences found between phenolic compounds could be related to their different chemical structures. Previous studies have shown that some hydroxybenzoic acids could inhibit bacterial metabolism (44). A possible explanation for this inhibitory effect is that some polyphenols can interact with cell enzymes (14). For some Lactobacillus species a stimulatory effect on growth at low concentrations has been described (38). These species can metabolize hydroxycinnamic acids by reduction to ethyl phenols, a non inhibitory form. Campos et al. (15) reported that important oenological characteristics of wine LAB, such as malolactic activity and volatile organic acids production, may 
be differently affected by the presence of phenolic acids, depending on the bacterial species or strain. The inhibitory effect of protocacheutic acid on L hilgardii is well reported for another metabolic system (2). However, this is the first work on the influence of phenolic compounds on the ADI system.

In Europe and part of America, several wines are made using spontaneous fermentation. L. hilgardii is usually found in the winemaking industry and is present in nearly all the spontaneous fermentations $(14,33,40,42)$. These bacteria survive because of their high tolerance to ethanol and their ability to carry out the malolactic fermentation desirable in wine. (26). However, they also present deleterious properties, like arginine degradation. Therefore, the study of the effect of phenolic compounds normally present in wine on arginine degradation is very important.

The results concerning the inhibitory effect of gallic and protocatechuic acids on the arginine deiminase enzyme are important considering the formation of toxic compounds. Arginine was catabolized to a very limited extent in presence of protocatechuic and gallic acids. As a consequence, the liberation into the medium of citrulline, a precursor of the carcinogenic EC, was little. Moreover, as these phenolic acids did not inhibit the ornithine transcarbamylase enzyme, the citrulline formed was degraded.

Protocatechuic acid, a human health beneficial compound for its antioxidant properties, seems to be a natural inhibitor of the synthesis of citrulline, a potential EC precursor. Hence, the wines containing a higher amount of this phenolic acid could be safer for human health.

\section{ACKNOWLEDGEMENTS}

The authors gratefully acknowledge the support of this work by the Consejo Nacional de Investigaciones Científicas y Técnicas (CONICET) and Consejo de Investigaciones de la Universidad Nacional de Tucumán (CIUNT).

\section{REFERENCES}

1. Alberto, M.R.; Arena M.E.; Manca de Nadra, M.C. (2002). A comparative survey of two analytical methods for identification and quantification of biogenic amines. Food Control 13, 125-129.

2. Alberto, M.R.; Arena, M.E.; Manca de Nadra, M.C. (2007). Putrescine production from agmatine by L. hilgardii: Effect of phenolic compounds. Food Control, 18, 898-903.

3. Alberto, M.R.; Farías, M.E.; Manca de Nadra, M.C. (2001). Effect of gallic acid and catechin on Lactobacillus hilgardii $5 \mathrm{w}$ growth and metabolism of organics compounds. J. Agric. Food Chem. 49, 43594363.

4. Alberto, M.R.; Farías, M.E.; Manca de Nadra, M.C. (2002). Effect of wine phenolic compounds on Lactobacillus hilgardii $5 \mathrm{w}$ viability. J. Food Prot. 65, 148-150.

5. Alberto, M.R.; Gómez-Cordovés, C.; Manca de Nadra, M.C. (2004). Metabolism of galllic acid and catechin by Lactobacillus hilgardii form wine. J. Agric. Food Chem. 52, 6465-6469.

6. Arena, M.E.; Landete J.M.; Manca de Nadra, M.C.; Pardo I., Ferrer S. (2008). Factors affecting the production of putrescine from agmatine by Lactobacillus hilgardii $\mathrm{X}_{1} \mathrm{~B}$ isolated from wine. J. Appl. Microbiol. 105, 158-165.

7. Arena, M.E.; Manca de Nadra, M.C. (2001). Biogenic amine production by Lactobacillus. J. Appl. Bacteriol. 90, 158-162.

8. Arena, M.E.; Manca de Nadra, M.C. (2005). Influence of ethanol and low $\mathrm{pH}$ on arginine and citrulline metabolim in lactic acid bacteria from wine. Res. Microbiol. 156, 858-864.

9. Arena, M.E.; Manca de Nadra, M.C.; Muñoz, R. (2002). The arginine deiminase pathway in the wine lactic acid bacterium Lactobacillus hilgardii $\mathrm{X}_{1} \mathrm{~B}$ : structural and functional study of the $\operatorname{arc} \mathrm{ABC}$ genes. Gene 301, 61-66.

10. Arena, M.E.; Saguir de Zucal, F.M.; Manca de Nadra, M.C. (1999). Arginine, citrulline and ornithine metabolism by lactic acid bacteria from wine. Int. J. Food Microbiol. 52, 155-161.

11. Arenque, I.; Gil, J.; Carret, R.; Bordons, A.; Reguant, C. (2009). Detection of arc genes related with the ethyl carbamate precursors in wine lactic acid bacteria. J. Agric. Food Chem. 57 (5), 1841-1847.

12. Bajpai, B.; Patil, S. (2008). A new approach to microbial production of gallic acid. Braz. J. Microbiol. 39 (4), 708-711.

13. Bradford, M.M. (1976). Rapid and sensitive method for the quantitation of microgram quantities of protein utilizing the principle of protein-dye binding. Anal. Biochem. 72, 248-254.

14. Campos, F.M.; Couto, J.A.; Hogg, T.A. (2003). Influence of phenolic acids on growth and inactivation of Oenococcus oeni and Lactobacillus hilgardii. J. Appl. Microbiol. 94, 167-174.

15. Campos, F.M.; Figueiredo, A.R.; Hogg, T.A.; Couto, J.A. (2009). Effect of phenolic acids on glucose and organic acid metabolism by lactic acid bacteria from wine. Food Microbiol. 26, 409-414.

16. Cavin, J.F.; Andioc, V.; Etievant, P.X.; Divies, C. (1993). Ability of wine lactic acid bacteria to metabolize phenol carboxylic acids. Am. J. Enol. Vitic. 44, 76-80. 
17. Cheyner, V.; Teissedre, P.L. (1998). Polyphénols En Enologie: Fondements Scientifiques Et Technologiques, Paris: Technique et Documentation, p. 323-324.

18. Converti, A.; Aliakbarian, B.; Domínguez, J.M.; Bustos Vázquez, G.; Perego, P. Microbial production of biovanillin. (2010). Braz. J. Microbiol. 41 (3), 519-530.

19. Curiel, J.A.; Rodríguez, H.; Landete, J.M; de las Rivas, B.; Muñoz, R. (2010). Ability of Lactobacillus brevis strains to degrade food phenolic acids. Food Chem. 120, 225-229.

20. Deschamps, F.C.; Ramos Pereira, L. (2002). Method for phenolic acid determination in forage cell Wall. R. Bras. Zootec. 31 (4), 1634-1639.

21. Figueiredo, A.R.; Campos, F.; de Freitas, V.; Hogg, T.; Couto, J.A. (2008). Effect of phenolic aldehydes and flavonoids on growth and inactivation of Oenococcus oeni and Lactobacillus hilgardii. Food Microbiol. 25 (1), 105-112.

22. Galvão de Lima, V.L.A.; Melo de Almeida, E.; Lima da Silva D. E. (2002). Total phenolics and carotenoids in surinam cherry. Sci. agric. (Piracicaba, Braz.) 59 (3), 447-450.

23. Liu, S.Q.; Pilone, G.J. (1998). A review: Arginine metabolism in wine lactic acid bacteria and its practical signicance. J. Appl. Microbiol. 84, 315-327.

24. Liu, S.Q.; Pritchard, G.G.; Hardman, M. J.; Pilone, G. J. (1996). Arginine catabolism in wine lactic acid bacteria: Is it via the arginine deiminase pathway or the arginase-urease pathway?. J. Appl. Bacteriol. $81,486-492$.

25. Malacrida, C.R.; Motta, S. da. (2005). Total phenolics and anthocyanins in grape juice. Ciênc. Tecnol. Aliment. 25, 4, 659-664.

26. Manca de Nadra, M.C.; Strasser de Saad, A.M. (1987). Effect of pH, sulfur dioxide and ethanol concentrations on the growth of lactic acid bacteria isolated from Cafayate (Argentina) wines. Microbiol. Alim. Nutr. 5, 241-245.

27. Mira de Orduña, R.; Patchett, M.L.; Liu, S.Q.; Pilone, G.J. (2001). Growth and arginine metabolism of the wine lactic acid bacteria Lactobacillus buchneri and Oenococcus oeni at different $\mathrm{pH}$ values and arginine concentrations. Appl. Environ. Microbiol. 67, 1657-1662.

28. Mirvish, S.S. (1968). The carcinogenic action and metabolism of urethan and N- hydroxyurethan. Adv. Cancer Res. 11, 1-42.

29. Oginsky, E.L. (1955). Arginine dihydrolase. Meth. Enzymol. 2, 374-378.

30. Oliver de Souza, G. (2007). Scientific debates and the production of the São Paulo wine, 1890-1930. Rev. Bras. Hist. 27 (54), 239-260.

31. Reguant, C.; Bordons, A.; Arola, L.; Rozès, N. (2000). Influence of phenolic compounds on the physiology of Enococcus ani. J. Appl. Microbiol. 88, 1065-1071.

32. Rodríguez, H.; Curiel, J.A.; Landete, J.M.; de las Rivas, B.; López de
Felipe, F.; Gómez-Cordovés, C.; Mancheño, J.M.; Muñoz, R. (2009). Food phenolics and lactic acid bacteria. Int. J. Food Microbiol. 132, 7990.

33. Rodríguez, H.; de las Rivas, B.; Muñoz R. (2007). Efficacy of recA gene sequence analysis in the identification and discrimination of Lactobacillus hilgardii strains isolated from stuck wine fermentations. Int. J. Food Microbiol. 115, 70-78.

34. Rozès, N.; Arola, L.; Bordons, A. (2003). Effect of phenolic compounds on the co-metabolism of citric acid and sugars by Oenococcus oeni from wine. Lett. Appl. Microbiol. 36, 337-341.

35. Russel, J.A. (1944). The colorimetric estimation of small amounts of ammonia by the phenol-hypoclorite reaction. J. Biol. Chem. 156, 457461 .

36. Spano, G.; Chieppa, G.; Beneduce, L.; Massa, S. (2004). Expression analysis of putative $\operatorname{arcA}$, arcB and arcC genes partially cloned from Lactobacillus plantarum isolated from wine. J. Appl. Microbiol. 96, 185193.

37. Spano, G.; Massa, S.; Arena, M.E.; Manca de Nadra, M.C. (2007). Arginine metabolism in wine Lactobacillus plantarum: in vitro activities of the enzymes arginine deiminase (ADI) and ornithine transcarbamilase (OTCase). Annals Microbiol. 57 (1), 67-70.

38. Stead, D. (1993). The effect of hydroxycinnamic acids on the growth of wine-spoilage lactic acid bacteria. J. Appl. Bacteriol. 75, 135-141.

39. Stevens, D.F.; Ough, C.S. (1993). Ethyl carbamate formation: reaction of urea and citrulline with ethanol in wine under low to normal temperature conditions. Am. J. Enol. Vitic. 44 (3), 309-312.

40. Strasser de Saad, A.M.; Manca de Nadra, M.C. (1987). Isolation and identification of the lactic acid bacteria from Cafayate (Argentina) wines. Microbiol. Alim. Nutr. 5, 45-49.

41. Tonon, T.; Bourdineud, J.P.; Lonvaud, A. (2001). Catabolisme de l'arginine par Oenococcus oeni: aspects énergétiques et génétiques. Lait $81,139-150$.

42. Tonon, T.; Lonvaud-Funel, A. (2002). Arginine metabolism by wine Lactobacili isolated from wine. Food Microbiol. 19, 451-461.

43. US Food and Drug Administration, Center for Food Safety and Nutrition. (2000). Information on ethyl carbamate (urethane) in foods and beverages. Available from: http://www.cfsan.fda.gov/ frf/ecintro.html.

44. Vivas, N.; Lonvaud-Funel, A.; Glories, Y. (1997). Effect of phenolic acids and anthocyanins on growth, viability and malolactic activity of a lactic acid bacterium. Food Microbiol. 14, 291-300.

45. Vrancken, G.; Rimaux, T.; Weckx, S.; De Vuyst L.; Leroy F. (2009). Environmental $\mathrm{pH}$ determines citrulline and ornithine release through the arginine deiminase pathway in Lactobacillus fermentum IMDO 13010. Int. J. Food Microbiol. 135, 216-222. 